\title{
UNIONIZATION, INDUSTRY CONCENTRATION, AND ECONOMIC GROWTH
}

\author{
Colin Davis \\ Ken-ichi Hashimoto \\ Ken Tabata
}

December 2021

The Institute of Social and Economic Research

Osaka University

6-1 Mihogaoka, Ibaraki, Osaka 567-0047, Japan 


\title{
Unionization, Industry Concentration, and Economic Growth
}

\author{
Colin Davis* Ken-ichi Hashimoto $^{\dagger}$ Ken Tabata ${ }^{\ddagger}$
}

December 2021

\begin{abstract}
This paper examines how unionization affects economic growth through its impact on industry concentration in a two-country model of international trade and endogenous productivity growth. Knowledge spillovers link firm-level productivity in innovation with geographic patterns of industry ensuring a faster rate of output when industry is relatively concentrated in the country with the greater labor supply. We show that stronger bargaining power in the relatively large country increases the rate of output growth when labor unions are employment-oriented, but decreases the rate of growth when unions are wage-oriented. We then calibrate the model using labor market data for the United States and the United Kingdom and study the effects of falling union bargaining power on industry location patterns, output growth, and national welfare.
\end{abstract}

Key Words: Labor Union Bargaining Power; Industry Concentration; Knowledge Diffusion; Endogenous Productivity Growth; Endogenous Market Structure

JEL Classifications: F43; O30; O40

*The Institute for the Liberal Arts, Doshisha University; (E-mail) cdavis@mail .doshisha. ac . jp

${ }^{\dagger}$ Graduate School of Economics, Kobe University; (E-mail) hash imoto@econ . kobe-u . ac . jp

${ }^{\sharp}$ School of Economics, Kwansei Gakuin University; (E-mail) tabataken@kwansei . ac . jp

Acknowledgements: This research was financially supported by the Joint Usage/Research Center at ISER (Osaka University) and KIER (Kyoto University), and the Japan Society for the Promotion of Science: Grantsin-Aid for Scientific Research 19K01638, 20H05631, 20K01569, 20 K01631. 


\section{Introduction}

There is a great diversity in levels of unionization and collective bargaining over wages across countries. These differences in labor market institutions influence industry location patterns through their impact on production costs. Although the direct effect of unionization on economic growth is generally ambiguous, industry location patterns are known to have important implications for economic growth, with greater industry concentration generating knowledge spillovers that promote faster rates of innovation. In this paper we consider how unionization affects economic growth through adjustments in industry location patterns.

We introduce an endogenous growth and endogenous market structure framework (Smulders and van de Klundert, 1995; Peretto, 1996, 2018; Young, 1998) that allows for a study of how unionization affects the geographic location of industry and economic growth. Our two-country framework consists of two industries. A final good sector employs labor and intermediate goods in the production of a homogeneous good. Firms in the intermediate sector employ final goods in the production of differentiated varieties and in process innovation aimed at reducing production costs. International trade costs on intermediate goods ensure that the country with the larger market (i.e., greater labor supply) hosts greater shares of the intermediate and final good industries, and has more productive intermediate firms. Imperfect knowledge diffusion between countries links the strength of knowledge spillovers with the geographic location of industry, generating a positive relationship between industry concentration and the rate of economic growth.

A key feature of our framework is the endogenous determination of national labor supplies through negotiation between a labor union and a federation of employers. Adopting the "managerial" labor union introduced by Pemberton (1988), the balance of internal power between leadership and membership determines union orientation, with important implications for the contract curve that arises from negotiation between the federation and the labor union. As a result, strengthening the wage orientation of the union lowers the national labor supply. An increase in union bargaining power, however, reduces the labor supply if the 
union is wage-oriented, and expands the labor supply if the union is employment-oriented (Pemberton, 1988; Chang et al., 2007; Chu et al., 2016).

We use the framework to explore how changes in labor union policy affect industry location patterns and the rate of economic growth. Beginning with union orientation, we find that strengthening the wage orientation of the labor union in the country with the larger labor supply decreases the large country's shares of intermediate and final good production, and lowers the relative productivity of its intermediate firms, as the national labor supply contracts. The reduced concentration of industry weakens knowledge spillovers, slowing the rate of growth. In contrast, strengthening the wage orientation of the small country labor union improves knowledge spillovers by raising industry concentration in the large country, and thus accelerates economic growth.

As seen above, the effects of changes in union bargaining power depend on union orientation. Focusing on the labor union of the large country, if the union is wage-oriented, an increase in union bargaining power lowers the concentration of industry in the large country, weakening knowledge spillovers and slowing economic growth. Alternatively, if the union is employment-oriented, the increase in bargaining power raises industry concentration, thereby strengthening knowledge spillovers and hastening economic growth. These mechanisms generate similar, but opposite, results for the effects of an increase in labor union bargaining power in the small country.

We explore the welfare implications of unionization through a numerical calibration of our model that uses labor market data to estimate union bargaining power for the US and the UK between 1980 and 2007 through an adaptation of the method introduced by Chu et al. (2016). The numerical analysis suggests that unions in the US and the UK were wageoriented over the period of analysis, and that the general decline in union bargaining power observed in these countries led to welfare improvements that were for the most part driven by expansions in national output levels. We also find that a fall in the rate of output growth generated small welfare losses for both countries. 
A broad empirical literature investigates the relationship between unionization and economic growth (Doucouliagos et al., 2017). Consider, for instance, a selection of studies examining data for OECD countries. On the one hand, Carmeci and Mauro (2003) and Nguyen-Can and Terraz (2021) report that increased union density and greater union centralization have negative effects on per capita income growth. Vernon and Rogers (2013), on the other hand, conclude that predominant union structure is important, with craft or general unions having negative, enterprise unions having negligible, and industrial unions having positive effects on labor productivity growth in manufacturing. Furthermore, the results of Storm and Naastepad (2009) suggest a positive role for labor unions through the effect of labor market regulation on labor productivity growth. More generally, however, the metaanalysis of Doucouliagos et al. (2017) concludes that there is no significant relationship between unionization and economic growth.

There is a diverse theoretical literature studying how unionization affects economic growth (Shister, 1954; Palokangos, 1996, 2005; Ramos-Parreno and Sanchez-Losada, 2002; Irmen and Wigger, 2002; Lingens, 2003, 2007). In particular, Chang et al. (2007) introduce a "managerial union" into a model of endogenous growth, and conclude that stronger union bargaining power reduces the labor supply and slows economic growth when the union is wageoriented, but expands the labor supply and hastens growth when the union is employmentorientated. In a similar vein, Chang and Hung (2016) consider a wage-oriented managerial union in combination with an elastic household labor supply, and show that greater union bargaining power promotes economic growth as a reduced number of workers increase their work hours in response to rising wages, expanding the effective labor supply. These results are closely linked, however, with a scale effect, whereby the growth rate increases proportionately with the labor force. Indeed, in a scale-neutral endogenous growth and endogenous market structure framework, Ji et al. (2016) show that the economy absorbs changes in union bargaining power through adjustments in market entry, leaving no impact on the long-run growth rate. Our paper extends the growth literature through a consideration of the indi- 
rect effects of unionization on scale-neutral economic growth that result from relationship between the relative market size and industry location patterns.

Accordingly, our paper is closely related with the new economic geography literature that explores the effects of unionization on industry location (Persyn, 2013; Egger and Etzel, 2014). In a two-country model of international trade, Picard and Toulemonde (2006) show that a symmetric increase in bargaining power across countries leads to a dispersed industry location pattern. Munch (2003) finds that industry tends to agglomerate in the country with weaker union bargaining power, although industry potentially agglomerates in the country with stronger union bargaining power over an intermediate range for international trade costs. Because these studies assume a negatively sloped or vertical contract curve, however, employment-oriented unions are not considered. Thus, our paper contributes to the literature with a study of how union orientation influences industry location patterns, with an emphasis on the implications of unionization for long-run growth.

The remainder of the paper is organized as follows. The next section introduces our two-country model of trade and endogenous productivity growth. Section 3 provides a characterization of the model's long-run equilibrium, and Section 4 studies how changes in the wage orientation and bargaining power of labor unions affect long-run economic growth. In Section 5, we calibrate the model using data for the US and the UK and study the long-run welfare implications of changes in labor union bargaining power. Section 6 concludes. Proofs are provided in the appendices.

\section{The Model}

This section develops a two-country model of trade and productivity growth. We refer to the two countries as home and foreign. A final good sector employs labor and intermediate goods in the production of a homogeneous good for sale to a competitive market. The intermediate goods sector consists of monopolistically competitive firms that employ final goods in the production of differentiated varieties and in process innovation that reduces production costs. 
The countries differ with respect to population size and labor market policy. In each country, negotiations between a federation of employers and a labor union determine national employment and the wage rate. In what follows, we focus on the home country as we introduce the model, but analogous conditions are derived for the foreign country.

\subsection{Households}

The lifetime utility of the representative dynastic household in the home country is

$$
U=\sum_{t=0}^{\infty} \frac{\ln C_{t}}{(1+\rho)^{t}}
$$

where $C_{t}$ denotes the consumption of final goods in period $t$, and $\rho>0$ is the subjective discount rate. The household maximizes lifetime utility (1) subject to the following asset accumulation equation:

$$
A_{t+1}=\left(1+r_{t}\right) A_{t}+w_{t} L_{t}+b_{t}\left(\bar{L}-L_{t}\right)+\Pi_{t}-T_{t}-C_{t}
$$

where $A_{t}$ is household assets, $r_{t}$ is the real interest rate, $w_{t}$ is the wage rate, $\bar{L}$ is the inelastic labor supply, $L_{t}$ is the number of employed workers, $b_{t}$ is the unemployment benefit provided to unemployed workers, $\Pi_{t}$ is dividend income derived from the profits of final good producers, and $T_{t}$ is a lump-sum tax levied by the government. The representative household eliminates consumption and employment uncertainty by ensuring equal consumption levels for all household members regardless of their employment status (Merz, 1995; Andolfatto, 1996). In addition, we adopt the final good as the model numeraire and set its price equal to one.

Solving this dynamic optimization problem, we derive the following Euler equation:

$$
\frac{C_{t+1}}{C_{t}}=\frac{1+r_{t+1}}{1+\rho} .
$$


Perfect international capital mobility ensures a common evolution for home and foreign household consumption, as the interest rate is equalized across countries: $C_{t+1} / C_{t}=C_{t+1}^{*} / C_{t}^{*}$ $=\left(1+r_{t+1}\right) /(1+\rho)$, where variables associated with foreign are indicated with an asterisk. The foreign household faces a similar utility maximization problem and therefore has similar demand conditions.

\subsection{Government}

A relatively passive role is set for the government: distributing unemployment benefits and levying a lump-sum $\operatorname{tax} T_{t}$ on the household to balance the fiscal budget. The balanced-budget condition is

$$
T_{t}=b_{t}\left(\bar{L}-L_{t}\right) .
$$

To avoid degeneration of unemployment benefits along the balanced-growth path, we assume that the unemployment benefit $b_{t}$ is linked proportionately with final output $Y_{t}$; that is, $b_{t}=m Y_{t}$, where $m>0$ is a policy that sets the ratio of the unemployment benefit to final good output in the home country. Similarly, the balanced-budget condition for the foreign government is $T_{t}^{*}=b_{t}^{*}\left(\bar{L}^{*}-L_{t}^{*}\right)$, with $b_{t}^{*}=m^{*} Y_{t}^{*}$, where $m^{*}>0$. Note that we allow unemployment benefit policies, $m$ and $m^{*}$, to differ across countries.

\subsection{Final Good Production}

Final goods are produced for an international market characterized by free trade. We adopt a Cobb-Douglas formation for the aggregate production function. For example, in the home country we have

$$
Y_{t}=Z_{t}^{\alpha} L_{t}^{\beta}
$$


where $Z_{t}$ is an intermediate composite and $L_{t}$ is labor employment. The factor intensities associated with the intermediate composite and labor are $\alpha \in(0,1)$ and $\beta \in(0,1)$. Following Palokangas (1996, 2005) and Chang et al. (2007), we assume that the production function exhibits decreasing returns to scale, with $\alpha+\beta<1$, thereby allowing final good producers to generate positive profits for the labor union and the employer federation to negotiate over.

The intermediate composite is formulated as a CES aggregator over the varieties available in period $t$ :

$$
Z_{t}=\left(\int_{0}^{n_{t}} x_{i, t}^{\epsilon} d i+\int_{0}^{n_{t}^{*}} x_{j, t}^{\epsilon} d j\right)^{\frac{1}{\epsilon}}
$$

where $x_{i, t}$ is the demand for intermediate variety $i$ of the $n_{t}$ mass of varieties produced in home, and $x_{j, t}$ is the demand for variety $j$ of the $n_{t}^{*}$ mass of varieties produced in foreign. The total mass of varieties is $N_{t} \equiv n_{t}+n_{t}^{*}$, and the constant elasticity of substitution between any given pair of varieties is measured by $1 /(1-\epsilon)$, with $\epsilon \in(0,1)$.

The profit function of the representative final good producer in the home country is

$$
\Pi_{t}=Y_{t}-w_{t} L_{t}-\int_{0}^{n_{t}} p_{i, t} x_{i, t} d i-\int_{0}^{n_{t}^{*}} p_{j, t}^{*} \tau x_{j, t} d j
$$

where $p_{i, t}$ is the price of intermediate variety $i$ produced in home, $p_{j, t}^{*}$ is the price of variety $j$ imported from foreign, and $\tau>1$ is an iceberg trade cost, under which $\tau$ additional units must be shipped for every unit sold in an export market.

Final good firms set their inputs of $x_{i, t}$ and $x_{j, t}$ to maximize profit (7), generating the following home country demand conditions for varieties produced in home and foreign:

$$
x_{i, t}=p_{i, t}^{\frac{-1}{1-\epsilon}} P_{Z, t}^{\frac{\epsilon}{1-\epsilon}} \alpha Y_{t}, \quad x_{j, t}=\left(\tau p_{j, t}^{*}\right)^{\frac{-1}{1-\epsilon}} P_{Z, t}^{\frac{\epsilon}{1-\epsilon}} \alpha Y_{t}
$$


where the home-country price index for intermediate varieties is

$$
P_{Z, t}=\left(\int_{0}^{n_{t}} p_{i, t}^{-\frac{\epsilon}{1-\epsilon}} d i+\varphi \int_{0}^{n_{t}^{*}} p_{j, t}^{*-\frac{\epsilon}{1-\epsilon}} d j\right)^{-\frac{1-\epsilon}{\epsilon}}
$$

and $P_{Z, t} Z_{t}=\alpha Y_{t}$. We index the level of trade costs using the freeness of trade $\varphi \equiv \tau^{-\frac{\epsilon}{1-\epsilon}} \in$ $(0,1)$; that is, $d \varphi / d \tau<0$, with $\varphi=0$ describing prohibitively high trade costs and $\varphi=$ 1 indicating free trade between countries. Final good producers in foreign solve a similar optimization problem generating analogous demand conditions for intermediate varieties.

\subsection{Labor Unions and Collective Bargaining}

Central to the labor market in our framework is the negotiations between the labor union and the employer federation that determine national employment and the wage rate. As in Pemberton (1988) and Chang et al. (2007), we consider a managerial labor union, in which union members desire a high wage rate while union leaders aim for a large membership. Formally, the union's objective function in the home country is set as

$$
O_{t}=\left(w_{t}-b_{t}\right)^{\chi} L_{t}
$$

where $\chi>0$ measures the weight the union places on incremental wage income from employment (i.e., the wage rate minus the unemployment benefit).

The bargaining problem involves choosing $w_{t}$ and $L_{t}$ to maximize the following Nash product: $O_{t}^{\psi} \Pi_{t}{ }^{1-\psi}$, where $\psi \in(0,1)$ denotes the relative bargaining power of the labor union. Solving this bargaining problem, we obtain the following optimal conditions for the wage rate and employment:

$$
\begin{aligned}
w_{t}-b_{t} & =\chi\left(w_{t}-\beta \frac{Y_{t}}{L_{t}}\right), \\
\frac{w_{t} L_{t}}{Y_{t}} & =\beta+\psi(1-\alpha-\beta),
\end{aligned}
$$


where we have used (7) and (10). The contract curve (11) describes the locus of points for which the union's indifference curve and the firm's isoprofit curve are tangent in $\left(w_{t}, L_{t}\right)$ space. The rent division curve (12) indicates the labor union's negotiated share of income.

The equilibrium level of employment is obtained through substitution of the rent curve (12) and $b_{t}=m Y_{t}$ into the contract curve (11):

$$
L=\frac{1}{m}[\beta+(1-\chi) \psi(1-\alpha-\beta)]
$$

Hence, we find that employment is decreasing in union wage orientation $(\chi)$. The relationship between union bargaining power and national employment is summarized as follows.

Lemma 1 An increase in union bargaining power $(\psi)$ expands employment $(L)$ for $\chi>1$, but contracts employment for $\chi<1$.

Following Chu et al. (2016), we use $\chi$ to describe the relative importance that the union places on wages over membership. When $\chi>1$, the contract curve has a negative slope, and we refer to the union as wage-oriented. In this first case, a rise in union bargaining power shifts the rent curve, causing a contraction in national employment. Alternatively, when $\chi<1$, the contract curve has a positive slope, and we refer to the union as employment-oriented. In this second case, an increase in bargaining power leads to an expansion in national employment. ${ }^{1}$

Analogous conditions are obtained for the foreign labor market: $w_{t}^{*}-b_{t}^{*}=\chi^{*}\left(w_{t}^{*}-\right.$ $\left.\beta Y_{t}^{*} / L_{t}^{*}\right), w_{t}^{*} L_{t}^{*} / Y_{t}^{*}=\beta+\psi^{*}(1-\alpha-\beta)$, and $L^{*}=\left(1 / m^{*}\right)\left[\beta+\left(1-\chi^{*}\right) \psi^{*}(1-\alpha-\beta)\right]$, where we allow union wage orientation $\left(\chi, \chi^{*}\right)$ and bargaining power $\left(\psi, \psi^{*}\right)$ to differ between home and foreign.

\subsection{Intermediate Good Production}

Intermediate firms employ final goods in the production of horizontally differentiated varieties for supply to the home and foreign markets under monopolistic competition (Dixit and

\footnotetext{
${ }^{1}$ In general, the empirical evidence lends more support to a wage-oriented structure for union preferences (Clark and Oswald, 1989).
} 
Stiglitz, 1977). Each firm survives for two periods. In the first, firms invest in market entry and process innovation, and in the second they produce an intermediate product variety.

The production technologies of intermediate firms located in home and foreign are

$$
X_{i, t}=\theta_{i, t}^{\gamma} I_{x, i, t}, \quad X_{j, t}^{*}=\theta_{j, t}^{*}{ }^{\gamma} I_{x, j, t}^{*}
$$

where $X_{i, t}$ and $X_{j, t}^{*}$ are firm-level outputs, $I_{x, i, t}$ and $I_{x, j, t}^{*}$ are firm-level inputs of final goods, $\theta_{i, t}$ and $\theta_{j, t}^{*}$ are firm-specific productivity coefficients, and $\gamma \in(0,1)$ is the output elasticity of productivity. Each intermediate firm produces to meet the combined demands from final good firms in home and foreign. For example, a home-based intermediate firm sets supply equal to $X_{i, t}=x_{i, t}+\tau x_{i, t}^{*}$.

Under monopolistic competition, the large mass of intermediate varieties sold in each market eliminates strategic interaction between firms as they choose their optimal production levels. Thus, each firm maximizes operating profit on sales, $\pi_{i, t} \equiv p_{i, t} X_{i, t}-I_{x, i, t}$, by setting price equal to a constant markup over unit cost; that is,

$$
p_{i, t}=\frac{1}{\epsilon \theta_{i, t}^{\gamma}}, \quad p_{j, t}^{*}=\frac{1}{\epsilon \theta_{j, t}^{*} \gamma},
$$

for home and foreign firms. Accordingly, optimal operating profit on sales can be obtained as $\pi_{i, t}=(1-\epsilon) p_{i, t} X_{i, t}=[(1-\epsilon) / \epsilon] I_{x, i, t}$. Substituting the demand conditions (8), the pricing rules (15), and $X_{i, t}=x_{i, t}+\tau x_{i, t}^{*}$ into $\pi_{i, t}=(1-\epsilon) p_{i, t} X_{i, t}$ yields the following expressions for the optimal operating profits

$$
\begin{aligned}
& \pi_{i, t}=\alpha(1-\epsilon) p_{i, t}^{-\frac{\epsilon}{1-\epsilon}}\left(P_{Z, t}^{\frac{\epsilon}{1-\epsilon}} Y_{t}+\varphi P_{Z, t}^{*} \frac{\epsilon}{1-\epsilon} Y_{t}^{*}\right), \\
& \pi_{j, t}^{*}=\alpha(1-\epsilon) p_{j, t}^{*-\frac{\epsilon}{1-\epsilon}}\left(\varphi P_{Z, t}^{\frac{\epsilon}{1-\epsilon}} Y_{t}+P_{Z, t}^{*} \frac{\epsilon}{1-\epsilon} Y_{t}^{*}\right),
\end{aligned}
$$

of home and foreign intermediate firms. 


\subsection{Process Innovation}

Intermediate firms employ final goods both in preparation for market entry and in process innovation. Specifically, to produce intermediate variety $i$ with productivity $\theta_{i, t}$ in home in period $t$, a firm must invest a fixed $f$ units of final goods in market entry and a variable $I_{R, i, t-1}$ units of final goods in process innovation in period $t-1$.

The productivities associated with the production technologies of home and foreign intermediate firms are generated by investment in process innovation as follows:

$$
\theta_{i, t}=\xi K_{t-1} I_{R, i, t-1}, \quad \theta_{j, t}^{*}=\xi K_{t-1}^{*} I_{R, j, t-1}^{*},
$$

where $K_{t-1}$ and $K_{t-1}^{*}$ are the productivities of home and foreign firms in $\mathrm{R} \& \mathrm{D}$, and $\xi>0$. Following the in-house process innovation literature (Smulders and van de Klundert, 1995; Peretto, 1996, 2018), we assume that technical knowledge accumulates within the production technology of each firm. Specifically, national stocks of knowledge are captured by the average productivity of the intermediate production technologies employed in each country: $\theta_{t} \equiv\left(1 / n_{t}\right) \int_{0}^{n_{t}} \theta_{i, t} d i$ and $\theta_{t}^{*} \equiv\left(1 / n_{t}^{*}\right) \int_{0}^{n_{t}^{*}} \theta_{j, t}^{*} d j$.

We then model the productivities of home and foreign firms in process innovation as the weighted average of the productivities of observable technical knowledge in period $t-1$, generating an intertemporal knowledge spillover from production to innovation. Knowledge spillovers in home and foreign are therefore

$$
K_{t-1}=s_{t-1} \theta_{t-1}+\delta s_{t-1}^{*} \theta_{t-1}^{*}, \quad \quad K_{t-1}^{*}=s_{t-1}^{*} \theta_{t-1}^{*}+\delta s_{t-1} \theta_{t-1},
$$

where $s_{t-1} \equiv n_{t-1} / N_{t-1}$ and $s_{t-1}^{*}=1-s_{t-1} \equiv n_{t-1}^{*} / N_{t-1}$. The degree of international knowledge diffusion is regulated by $\delta \in(0,1)$, with knowledge spillovers that are completely national in scope for $\delta=0$, and perfect international knowledge diffusion for $\delta=1$.

In period $t-1$, firms borrow from households to finance the costs of market entry and process innovation. As in Young (1998), the net present values of home and foreign firms in 
period $t-1$ are

$$
V_{i, t-1}=\frac{\pi_{i, t}}{1+r_{t}}-\left(I_{R, i, t-1}+f\right), \quad V_{j, t-1}^{*}=\frac{\pi_{j, t}^{*}}{1+r_{t}}-\left(I_{R, j, t-1}^{*}+f\right),
$$

where we assume that fixed entry costs are symmetric across countries $\left(f=f^{*}\right)$.

Firms choose their optimal levels of investment in innovation, $I_{R, i, t-1}$ and $I_{R, j, t-1}^{*}$ to maximize firm value (19) subject to the technology constraint (17). From the first-order conditions (i.e., $\partial V_{t-1} / \partial I_{R, j, t-1}=\partial V_{t-1}^{*} / \partial I_{R, j, t-1}^{*}=0$ ), we obtain

$$
I_{R, i, t-1}=\frac{\eta \pi_{i, t}}{1+r_{t}}, \quad I_{R, j, t-1}^{*}=\frac{\eta \pi_{j, t}^{*}}{1+r_{t}}
$$

with $\eta \equiv \gamma \epsilon /(1-\epsilon)$. These expressions imply that firms located in the same country have symmetric productivity levels, and therefore set the same prices and employment levels for production and innovation. Henceforth, we omit the indices $i$ and $j$, with $\theta_{i, t}=\theta_{t}$ and $\theta_{j, t}^{*}=\theta_{t}^{*}$. Moreover, substituting (20) into (19), we rewrite the net present values of home and foreign firms in period $t-1$ as

$$
V_{t-1}=\frac{(1-\eta) \pi_{t}}{1+r_{t}}-f, \quad \quad V_{t-1}^{*}=\frac{(1-\eta) \pi_{t}^{*}}{1+r_{t}}-f
$$

We assume that $\eta \equiv \gamma \epsilon /(1-\epsilon)<1$ in order to satisfy the second-order condition for the maximization of firm value.

\subsection{Market Entry}

Firm value drives market entry and exit in the intermediate sector in each country. Specifically, with no costs incurred in the introduction of new product designs, firms enter the intermediate sector when firm value is positive $\left(V_{t-1}>0\right)$ and exit when firm value is negative $\left(V_{t-1}<0\right)$. Referencing (9), (16), and (21), firm value responds correctly to market entry and exit $\left(\partial V_{t-1} / \partial n_{t}<0\right.$ and $\left.\partial V_{t-1}^{*} / \partial n_{t}^{*}<0\right)$, and thus the level of market entry in each country 
adjusts immediately, forcing firm value to zero $\left(V_{t-1}=V_{t-1}^{*}=0\right)$ at all moments in time, in the spirit of Novshek and Sonnenchen (1987).

A key implication of free market entry and exit, in combination with the integrated financial market, is common scales of production and process innovation across firms in both countries. ${ }^{2}$ Substituting (20) and (21) into $V_{t-1}=V_{t-1}^{*}=0$ yields equilibrium firm-level investment in process innovation as $I_{R} \equiv I_{R, t-1}=I_{R, t-1}^{*}=\eta f /(1-\eta)$. As such, using (18) with (17), the productivity growth rates of intermediate firms in home and foreign are

$$
\begin{aligned}
& g_{\theta}\left(\tilde{\theta}_{t-1}\right) \equiv \frac{\theta_{t}}{\theta_{t-1}}=\frac{K_{t-1}}{\theta_{t-1}} \xi I_{R}=\left[s_{t-1}+\delta\left(1-s_{t-1}\right) \tilde{\theta}_{t-1}^{-1}\right] \xi I_{R}, \\
& g_{\theta}^{*}\left(\tilde{\theta}_{t-1}\right) \equiv \frac{\theta_{t}^{*}}{\theta_{t-1}^{*}}=\frac{K_{t-1}^{*}}{\theta_{t-1}^{*}} \xi I_{R}=\left[1-s_{t-1}+\delta s_{t-1} \tilde{\theta}_{t-1}\right] \xi I_{R},
\end{aligned}
$$

where $\tilde{\theta}_{t} \equiv \theta_{t} / \theta_{t}^{*}$ denotes the international productivity differential. These expressions show that firm-level productivity growth depends solely on knowledge spillovers $\left(K_{t} / \theta_{t}\right.$ and $\left.K_{t}^{*} / \theta_{t}^{*}\right)$, and is therefore closely linked with national shares of intermediate production $\left(s_{t}\right)$ and the international productivity differential $\left(\tilde{\theta}_{t}\right)$.

\subsection{Market Equilibrium}

We now characterize the market clearing conditions for the intermediate and final good sectors. First, with perfect capital mobility between countries, the total asset holdings of households equals total lending to home and foreign firms: $A_{t+1}+A_{t+1}^{*}=\left(I_{R}+f\right) n_{t+1}+\left(I_{R}^{*}+\right.$ f) $n_{t+1}^{*}$. Combining this expression with (19) and the free entry conditions $V_{t-1}=V_{t-1}^{*}=0$ implies that $\left(1+r_{t+1}\right)\left(A_{t+1}+A_{t+1}^{*}\right)=\pi_{t+1} n_{t+1}+\pi_{t+1}^{*} n_{t+1}^{*}$.

Next, the market clearing condition for intermediate goods is given by

$$
\alpha Y_{t}^{w}=n_{t} p_{t} X_{t}+n_{t}^{*} p_{t}^{*} X_{t}^{*}
$$

\footnotetext{
${ }^{2}$ Substituting $\pi_{t}=[(1-\epsilon) / \epsilon] I_{x, t}$ into $(21)$ and setting $V_{t-1}=V_{t-1}^{*}=0$ delivers the equilibrium scale of production as $I_{x, t}=I_{x, t}^{*}=[\epsilon /(1-\epsilon)][(1+r) f /(1-\eta)]$.
} 
where $Y_{t}^{w} \equiv Y_{t}+Y_{t}^{*}$. The lefthand side is the sum of home and foreign final good firms' expenditure on intermediate goods. The righthand side is the total revenue of home and foreign intermediate firms.

Lastly, the market clearing condition for final goods is given by

$$
Y_{t}^{w}=C_{t}^{w}+N_{t} I_{x, t}+N_{t+1}\left(I_{R}+f\right),
$$

where $C_{t}^{w} \equiv C_{t}+C_{t}^{*}$. Thus, the world supply of final goods is set to meet household consumption, total employment in intermediate production, and total employment in process innovation and market entry.

\section{Long-run Equilibrium}

In this section we derive two implicit conditions for the determination of national shares of intermediate firms $\left(s_{t}\right)$ and the international productivity differential $\left(\tilde{\theta}_{t}=\theta_{t} / \theta_{t}^{*}\right)$ in order to characterize the steady-state equilibrium of the model. We then derive the long-run rate of productivity growth along with national welfare levels. Focusing on steady states that exhibit a constant international productivity differential and a common rate of productivity growth across countries $\left(g_{\theta}=g_{\theta}^{*}\right)$, we consider balance growth paths that generate a constant rate of growth in household consumption $\left(C_{t+1} / C_{t}\right)$.

\subsection{Steady-state Industry Location Patterns}

The first condition for the determination of $s_{t}$ and $\tilde{\theta}_{t}$ is obtained by recalling that free market entry and exit reduces the value of intermediate firms to zero $\left(V_{t-1}=V_{t-1}^{*}=0\right)$. Then, the integrated financial market implies that all firms have the same level of operating profit; that is, $\pi_{t}=\pi_{t}^{*}$ at all moments in time. In Appendix A, we combine $\pi_{t}=\pi_{t}^{*}$ with $Y_{t} / Y_{t}^{*}=\left(Z_{t} / Z_{t}^{*}\right)^{\alpha}\left(L_{t} / L_{t}^{*}\right)^{\beta}, Y_{t} / Y_{t}^{*}=\left(P_{Z, t} Z_{t}\right) /\left(P_{Z, t}^{*} Z_{t}^{*}\right),(9),(15)$, and (16) to solve for the 
equilibrium share of intermediate firms based in home at time $t$ as

$$
s_{R, t}=\frac{\left(\tilde{\theta}_{t}^{\eta}-\varphi\right) y_{t}-\varphi\left(1-\varphi \tilde{\theta}_{t}^{\eta}\right)}{\left(\tilde{\theta}_{t}^{\eta}-\varphi\right)\left(1-\varphi \tilde{\theta}_{t}^{\eta}\right)\left(1+y_{t}\right)}, \quad y_{t} \equiv \frac{Y_{t}}{Y_{t}^{*}}=\left(\frac{L}{L^{*}}\right)^{\frac{\beta \epsilon}{\epsilon-\alpha}}\left(\frac{\tilde{\theta}_{t}^{\eta}-\varphi}{1-\varphi \tilde{\theta}_{t}^{\eta}}\right)^{\frac{\alpha(1-\epsilon)}{\epsilon-\alpha}}
$$

where $\epsilon>\alpha$ is required to ensure that productivity growth generates a positive rate of growth in final good output (see Section 3.2). This expression is illustrated by the $s_{R}$ curve in Figure 1, and has a strictly positive slope: $\partial s_{R, t} / \partial \tilde{\theta}_{t}>0 .^{3}$ An increase in the international productivity differential $\left(\tilde{\theta}_{t}\right)$ generates an expansion in the home share of intermediate firms through two channels. The first is a direct effect, whereby an improvement in the relative productivity of home-based firms expands their market share $\left(\partial s_{R, t} / \partial \tilde{\theta}_{t}>0\right)$. The second channel is an indirect effect, wherein international trade costs ensure that an increase in $\tilde{\theta}_{t}$ raises the home country's share of final good production $\left(\partial y_{t} / \partial \tilde{\theta}_{t}>0\right)$ as the relative cost of sourcing home produced intermediate goods falls. The expansion of the home market relative to foreign leads to a greater share of intermediate good producers for home $\left(\partial s_{R, t} / \partial y_{t}>0\right)$. Because the home share of intermediate firms is bounded $\left(s_{t} \in(0,1)\right)$, however, there are limits on the range of values for the international productivity differential, outside of which an equilibrium with active intermediate sectors in both countries is not feasible; that is, $\tilde{\theta}_{t} \in\left(\tilde{\theta}_{l}, \tilde{\theta}_{u}\right)$.

Next, we derive a differential equation to describe the dynamics of the international productivity differential. Referencing (22), we have

$$
\frac{\tilde{\theta}_{t+1}}{\tilde{\theta}_{t}}=\frac{g_{\theta}\left(\tilde{\theta}_{t}\right)}{g_{\theta}^{*}\left(\tilde{\theta}_{t}\right)}=\frac{K_{t} / \theta_{t}}{K_{t}^{*} / \theta_{t}^{*}}=\frac{s_{t}+\delta\left(1-s_{t}\right) \tilde{\theta}_{t}^{-1}}{1-s_{t}+\delta s_{t} \tilde{\theta}_{t}} .
$$

Thus, we naturally find that a constant productivity differential $\left(\tilde{\theta}_{t+1} / \tilde{\theta}_{t}=1\right)$ is synonymous with equal productivity growth rates for home and foreign intermediate firms $\left(g_{\theta}=g_{\theta}^{*}\right)$.

\footnotetext{
${ }^{3}$ The derivative of (25) with respect to the international productivity differential is

$$
\frac{\partial s_{R, t}}{\partial \tilde{\theta}_{t}}=\left[\frac{y_{t}}{\left(1-\varphi \tilde{\theta}_{t}^{\eta}\right)^{2}}+\frac{1}{\left(\varphi-\tilde{\theta}_{t}^{\eta}\right)^{2}}\right] \frac{\eta \varphi \tilde{\theta}_{t}^{\eta-1}}{1+y_{t}}+\frac{\left(1-\varphi^{2}\right) \tilde{\theta}_{t}^{\eta}}{\left(\tilde{\theta}_{t}^{\eta}-\varphi\right)\left(1-\varphi \tilde{\theta}_{t}^{\eta}\right)\left(1+y_{t}\right)^{2}} \frac{\partial y_{t}}{\partial \tilde{\theta}_{t}}>0
$$
}

with $\partial y_{t} / \partial \tilde{\theta}_{t}>0$. 
Figure 1: Determination of the International Productivity Differential $(\tilde{\theta})$

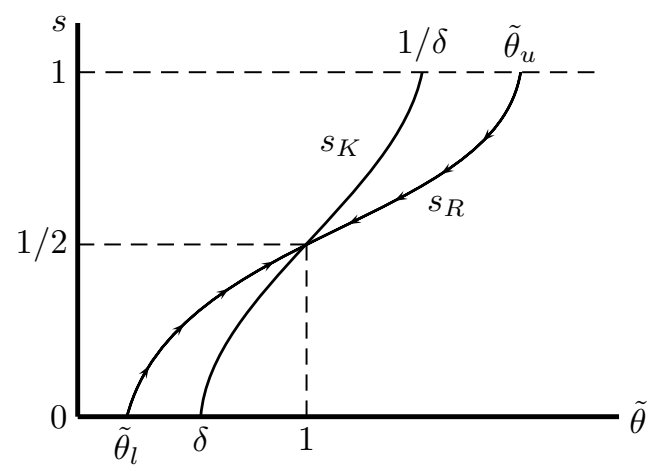

With all firms employing the same level of final goods in process innovation $\left(I_{R}=I_{R}^{*}\right)$, the constant productivity differential and equalized productivity growth rates require that firms have access to the same level of knowledge spillovers $\left(K_{t} / \theta_{t}=K_{t}^{*} / \theta_{t}^{*}\right)$, allowing us to derive the following steady-state condition for the home country's share of intermediate firms using (18):

$$
s_{K}(\tilde{\theta})=\frac{1-\delta \tilde{\theta}^{-1}}{2-\delta \tilde{\theta}-\delta \tilde{\theta}^{-1}}
$$

where we now drop the time script to indicate that steady-state values are constant. As shown by the $s_{K}$ curve in Figure 1, when the international productivity differential $(\tilde{\theta})$ increases, a greater share of firms is required for home to offset the improved access of foreign-based firms to technical knowledge $\left(\partial s_{K} / \partial \tilde{\theta}>0\right)$. Note that $\tilde{\theta} \in(\delta, 1 / \delta)$ is required for $s_{K} \in$ $(0,1)$. In addition, the slope of the $s_{K}$ curve is closely linked to the degree of knowledge diffusion. With perfect international knowledge diffusion $(\delta=1)$, the $s_{K}$ curve becomes a vertical line at $\tilde{\theta}=1$, and the international productivity differential vanishes.

In Appendix B, we study the local dynamics around the steady state characterized by the intersection of the $s_{K}$ and $s_{R}$ curves in Figure 1, and obtain the following proposition.

Proposition 1 The international productivity differential $(\tilde{\theta})$ converges to a long-run equi- 
librium with $s \in(0,1)$ when $\partial s_{K} / \partial \tilde{\theta}>\partial s_{R} / \partial \tilde{\theta}$.

Proof: See Appendix B.

As a state variable, the international productivity differential is rising (falling) for values of $\tilde{\theta}$ to the left (right) of the $s_{K}$ curve. Therefore, a stable steady state requires $\partial s_{K} / \partial \tilde{\theta}>$ $\partial s_{R} / \partial \tilde{\theta}$, as depicted in Figure 1. Examining (25), we find that $\lim _{\varphi \rightarrow 0} \tilde{\theta}_{l}=0$ and $\lim _{\varphi \rightarrow 0} \tilde{\theta}_{u}=$ $\infty$. Accordingly, we assume that the freeness of trade $(\varphi)$ is small enough to satisfy $\tilde{\theta}_{l}<\delta<$ $1 / \delta<\tilde{\theta}_{u}$, ensuring the existence of at least one steady state with the slope ranking outlined in Proposition 1. Hereafter, we focus on equilibria that satisfy these conditions for the existence of a stable long-run equilibrium.

The long-run international productivity differential $(\tilde{\theta})$ is implicitly linked with the relative employment level of the home country $\left(L / L^{*}\right)$. Referencing (25), an increase in $L / L^{*}$ expands the relative market size of the home country for intermediate producers $\left(\partial y / \partial\left(L / L^{*}\right)>\right.$ $0)$, causing an upward shift in the $s_{R}$ curve in Figure $1\left(\partial s_{R} / \partial y>0\right)$. As a result, the home country's shares of intermediate firms $(s)$ and final good production $(y)$ both increase. The rise in $s$ coincides with an increase in the international productivity differential that returns knowledge spillovers back to equality across countries $\left(K / \theta=K^{*} / \theta^{*}\right)$, as the economy converges to a new long-run equilibrium. These results are summarized in the following lemma.

Lemma 2 An increase in the relative employment of home $\left(L / L^{*}\right)$ expands the home country's shares of intermediate firms ( $s$ ) and final good production (y), while raising the international productivity differential $(\tilde{\theta})$.

From the results of Lemma 2 and the mechanics of Figure 1, referencing (25) and (27), it becomes clear that equality of national employment levels generates a symmetric equilibrium with $y=1, s=1 / 2$ and $\tilde{\theta}=1$. Accordingly, when home employment rises above foreign employment $\left(L / L^{*}>1\right)$, the home country has greater shares of intermediate firms $(s>1 / 2)$ and final good production $(y>1)$, and relatively productive intermediate firms $(\tilde{\theta}>1)$. When the foreign country has a larger relative employment level $\left(L / L^{*}<1\right)$, however, it 
has greater shares of intermediate firms $(s<1 / 2)$ and final good production $(y<1)$, and foreign-based intermediate firms are relatively productive $(\tilde{\theta}<1)$.

As we have seen, knowledge spillovers equalize across countries in the long run. Substituting (27) back into (18), and reorganizing the result, yields the steady-state level of knowledge spillovers as follows:

$$
\frac{K}{\theta}=\frac{K^{*}}{\theta^{*}}=\frac{1-\delta^{2}}{2-\delta \tilde{\theta}-\delta \tilde{\theta}^{-1}}
$$

Therefore, we find that $K / \theta$ is convex in the international productivity differential $(\tilde{\theta})$ with a minimum at $\tilde{\theta}=1$; that is, $\partial(K / \theta) / \partial \tilde{\theta}=-\left[\delta\left(1-\tilde{\theta}^{2}\right) /\left(1-\delta^{-2}\right) \tilde{\theta}^{2}\right](K / \theta)^{2}$. For $\tilde{\theta}<1$

an increase $\tilde{\theta}$ lowers knowledge spillovers, and for $\tilde{\theta}>1$ the increase in $\tilde{\theta}$ raises knowledge spillovers. Consequently, we find that firm-level productivity in R\&D is directly linked with national shares of intermediate production, with an increase in the geographic concentration of industry in one country raising the level of knowledge spillovers.

Lastly, before leaving this section, we derive the equilibrium operating profit associated with the intermediate firms based in home and foreign as

$$
\pi_{t}=\frac{\alpha(1-\epsilon) Y_{t}^{w}}{N_{t}}
$$

where we have used $\pi_{t}=(1-\epsilon) p_{t} X_{t}$ and $\pi_{t}=\pi_{t}^{*}$ in the market clearing condition for intermediate goods (23).

\subsection{Economic Growth}

We now turn to the long-run rate of output growth. First, combining (3), (21), and (29) with $V_{t-1}=V_{t-1}^{*}=0$, we rewrite the dynamics of household consumption as

$$
\frac{C_{t+1}}{C_{t}}=\frac{\alpha(1-\epsilon)(1-\eta)}{(1+\rho) f} \frac{Y_{t+1}^{w}}{N_{t+1}} .
$$


Figure 2: Long-run Output Growth

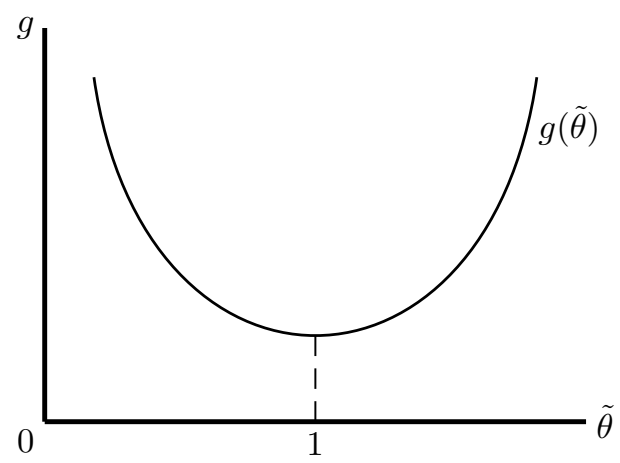

Because we are interested in balanced growth paths that feature a constant rate of growth in consumption for home and foreign households, this expression implies that final good output and the mass of intermediate firms grow at the same rate. In addition, given that $y \equiv Y_{t} / Y_{t}^{*}$ is constant in a steady state with a constant international productivity differential $\left(\tilde{\theta}_{t+1} / \tilde{\theta}_{t}=1\right)$, we find that $Y_{t+1}^{w} / Y_{t}^{w}=Y_{t+1} / Y_{t}=Y_{t+1}^{*} / Y_{t}^{*}=N_{t+1} / N_{t}$.

Then, substituting (5), (9), (15), (17), and (28) with $\alpha Y_{t}=P_{Z, t} Z_{t}$ into $Y_{t+1} / Y_{t}$ delivers the long-run rate of output growth as follows:

$$
g \equiv \frac{Y_{t+1}^{w}}{Y_{t}^{w}}=g_{\theta}^{\frac{\alpha \epsilon \gamma}{\epsilon-\alpha}}=\left[\frac{\left(1-\delta^{2}\right) \xi I_{R}}{2-\delta \tilde{\theta}-\delta \tilde{\theta}^{-1}}\right]^{\frac{\alpha \epsilon \gamma}{\epsilon-\alpha}}
$$

where $I_{R}=\eta f /(1-\eta)$. A casual examination of this expression makes it clear that knowledge spillovers are the key channel through which intermediate and final good production patterns affect the steady-state rate of output growth. As such, referencing (28), we find that the output growth rate is concave in the international productivity differential $(\tilde{\theta})$ with a minimum at $\tilde{\theta}=1$, as depicted in Figure 2. In addition, (31) indicates that the long-run growth rate is scale-invariant as proportionate changes in the labor forces of home and foreign leave the international productivity differential and the rate of output growth unchanged.

The mechanics of Figure 2, combined with Lemma 2, yield the following result.

Lemma 3 An increase in the relative employment of home $\left(L / L^{*}\right)$ depresses steady-state 
output growth $(g)$ for $\tilde{\theta}<1$ and accelerates output growth for $\tilde{\theta}>1$.

Changes in the relative employment of home $\left(L / L^{*}\right)$ only affect output growth $(g)$ indirectly through adjustments in the international productivity differential $(\tilde{\theta})$. Returning to Lemma 2 , because $\partial \tilde{\theta} / \partial\left(L / L^{*}\right)>0$, an increase in the relative employment of home generates a rightward movement along the $g(\tilde{\theta})$ curve in Figure 2. Specifically, the increase in $L / L^{*}$ expands the home country's shares of intermediate firms and final good production while raising the relative productivity of home-based firms. As a result, knowledge spillovers $(K / \theta)$ fall causing slower output growth when $\tilde{\theta}<1$ and knowledge spillovers rise leading to faster output growth when $\tilde{\theta}>1$.

The level of market entry in the intermediate sector $\left(N_{t}\right)$ depends on the international productivity differential $(\tilde{\theta})$ and the rate of output growth $(g)$. To emphasize this point, we first use (5), (9), (15), and (25) to derive final good output in home and foreign as

$$
Y_{t}=\frac{\left(\alpha \epsilon \theta_{t}^{\gamma}\right)^{\frac{\alpha}{1-\alpha}}\left(1-\varphi^{2}\right)^{\nu} N_{t}^{\nu} L^{\frac{\beta}{1-\alpha}}}{\left[\left(1-\varphi \tilde{\theta}^{\eta}\right)(1+1 / y)\right]^{\nu}}, \quad Y_{t}^{*}=\frac{\left(\alpha \epsilon \theta_{t}^{\gamma}\right)^{\frac{\alpha}{1-\alpha}}\left(1-\varphi^{2}\right)^{\nu} N_{t}^{\nu} L^{* \frac{\beta}{1-\alpha}}}{\left[\left(\tilde{\theta}^{\eta}-\varphi\right)(1+y)\right]^{\nu}}
$$

where $\nu \equiv \alpha(1-\epsilon) /((1-\alpha) \epsilon)<1$. An examination of these expressions shows that $N_{t+1} / N_{t}=Y_{t+1} / Y_{t}=Y_{t+1}^{*} / Y_{t}^{*}=g$ in the long-run equilibrium. A corollary of this result is that $C_{t+1} / C_{t}=g$, and referencing (3) the steady-state interest rate is therefore constant: $1+r=(1+\rho) g$.

Substituting these final output levels into $\pi=\alpha(1-\epsilon) Y_{t}^{w} / N_{t}=(1+\rho) f g /(1-\eta)$, we then obtain the total mass of intermediate firms along the balance growth path as follows:

$$
N_{t}=\theta_{t}^{\frac{\alpha \epsilon \gamma}{\epsilon-\alpha}}\left[\frac{\Gamma}{(1+\rho) g f}\right]^{\frac{1}{1-\nu}}\left\{\frac{L^{\frac{\beta}{1-\alpha}}}{\left[\left(1-\varphi \tilde{\theta}^{\eta}\right)(1+1 / y)\right]^{\nu}}+\frac{L^{* \frac{\beta}{1-\alpha}}}{\left[\left(\tilde{\theta}^{\eta}-\varphi\right)(1+y)\right]^{\nu}}\right\}^{\frac{1}{1-\nu}}
$$

with $\Gamma \equiv \alpha^{1 /(1-\alpha)}(1-\eta)(1-\epsilon) \epsilon^{\alpha /(1-\alpha)}\left(1-\varphi^{2}\right)^{\nu}$. Hence, we find that for a given level of home productivity $(\theta)$, our model features the standard tradeoff the arises between market entry and economic growth in endogenous growth and endogenous market structure frameworks. In 
addition, the mass of intermediate firms adjusts to absorb proportionate changes in the labor forces of home and foreign, ensuring a scale-invariant rate of output growth.

Although productivity growth drives market entry and the expansion of aggregate output along the balance growth path, adjustments in the international productivity differential $(\tilde{\theta})$ generally have an ambiguous effect on market entry, as an increase in $\tilde{\theta}$ expands the final good output of home, but contracts the final good output of foreign, while generating an ambiguous effect on the rate of output growth $(g)$, as seen in Lemma 3 .

\subsection{Social Welfare}

Lastly, we solve for the steady-state welfare levels of households in each country. Using (1) and (3), we express the lifetime welfare of home and foreign households along on the balanced growth path as

$$
U_{0}=\frac{1+\rho}{\rho}\left(\ln C_{0}+\frac{1}{\rho} \ln g\right), \quad U_{0}^{*}=\frac{1+\rho}{\rho}\left(\ln C_{0}^{*}+\frac{1}{\rho} \ln g\right)
$$

Household welfare derives from the current level of consumption $\left(C_{0}\right)$ and the growth of consumption $(g)$. In Appendix C, we derive steady-state consumption as follows:

$$
C_{0}=(1-\alpha) Y_{0}+\frac{\rho f N_{0} g}{2(1-\eta)}, \quad C_{0}^{*}=(1-\alpha) Y_{0}^{*}+\frac{\rho f N_{0} g}{2(1-\eta)}
$$

where we have set the initial value of home-firm productivity to unity $\left(\theta_{0}=1\right)$, and we have assumed that initial asset wealth is the same for home and foreign $\left(A_{0}=A_{0}^{*}\right)$. With $Y_{0}, Y_{0}^{*}$, and $N_{0}$ determined by (32) and (33), from the above expressions, we find that labor union policy influences welfare through its effects on domestic output levels $\left(Y_{0}\right.$ and $\left.Y_{0}^{*}\right)$, market entry $\left(N_{0}\right)$, and the rate of output growth $(g)$. 


\section{Labor Unions}

This section investigates how changes in the wage orientation and bargaining power of the home-country labor union affect output growth.

\subsection{Wage Orientation of Labor Unions}

We begin with an examination of the effects of a rise in the wage orientation $(\chi)$ of the homecountry labor union. ${ }^{4}$ The results are summarized in the following proposition.

Proposition 2 An increase in the wage orientation of the home-country labor union $(\chi)$ depresses output growth $(g)$ for $L / L^{*}>1$, and accelerates output growth for $L / L^{*}<1$.

Referring back to (13), an increase in $\chi$ leads to lower employment in home $(d L / d \chi<0)$, with the labor union's push for higher wages depressing labor demand. Consequently, the relative employment of home $\left(L / L^{*}\right)$ falls, reducing the home country's shares of intermediate firms $(s)$ and final good production $(y)$, and lowering the international productivity differential $(\tilde{\theta})$, as outlined in Lemma 2. Referencing Lemma 3, the fall in $L / L^{*}$ causes an adjustment in knowledge spillovers $(K / \theta)$ that accelerates output growth for $\tilde{\theta}<1$ and depresses output growth for $\tilde{\theta}>1$.

\subsection{Bargaining Power of Labor Unions}

Next, we consider how an adjustment in the bargaining power $(\psi)$ of the home-country labor union affects output growth $(g)$. From (13), we find that the effect of a change in bargaining power on national employment depends critically on the slope of the contract curve, as described by the wage orientation $(\chi)$ of the labor union, with $d L / d \psi<0$ for $\chi>1$ and $d L / d \psi>0$ for $\chi<1$. In the former case, the wage-oriented labor union demands higher wages as its bargaining power increases, thereby depressing labor demand. In the

\footnotetext{
${ }^{4}$ In our framework, raising unemployment benefits $m$ has the same effect as increasing wage orientation $\chi$.
} 
latter case, the employment-oriented labor union negotiates greater employment by allowing lower wages and expanding labor demand.

The effects of changes in bargaining power on labor employment have important implications for the rate of output growth, as summarized in the following proposition.

Proposition 3 If the home-country labor union is wage-oriented $(\chi>1)$, an increase in bargaining power $(\psi)$ slows output growth $(g)$ for $L / L^{*}>1$, and accelerates output growth for $L / L^{*}<1$. If the labor union is employment-oriented $(\chi<1)$, however, an increase in $\psi$ accelerates output growth for $L / L^{*}>1$, and slows output growth for $L / L^{*}<1$.

As we have seen, when the home-country labor union is wage orientated $(\chi>1)$, an increase in bargaining power $(\psi)$ reduces the home labor supply, leading to a fall in relative employment $\left(L / L^{*}\right)$ that lowers knowledge spillovers $(K / \theta)$ and depresses output growth for $L / L^{*}>1$, but raises knowledge spillovers and hastens output growth for $L / L^{*}<1$, following Lemma 3. In contrast, when the labor union is employment orientated $(\chi<1)$, a rise in bargaining power expands the home labor supply, generating an increase in relative employment $\left(L / L^{*}\right)$ that raises knowledge spillovers and accelerates economic growth for $L / L^{*}>1$, but lowers knowledge spillovers and slows output growth for $L / L^{*}<1$.

\section{Numerical Analysis}

The complex nature of our framework renders a theoretical study of welfare intractable. In this section, we calibrate the model using data for the income share of labor and employment in the US and the UK over the period from 1980 to 2007 with the aim of investigating how changes in labor union bargaining power affect national welfare by inducing shifts in industry location patterns. We set the US as the home country and the UK as the foreign country.

Table 1 provides a summary of the model parameters. First, the discount rate is fixed to $\rho=0.024$ following Jones et al. (1993). Then, in the final goods sector, we follow Chu et al. (2016) in assuming values of $\alpha=0.2$ and $\beta=0.5$ for the respective factor intensities 
Table 1: Parameter Values

\begin{tabular}{ccc}
\hline \hline Parameter & Description & Value \\
\hline$\rho$ & Discount rate & 0.024 \\
$\alpha$ & Intermediate intensity in final production & 0.2 \\
$\beta$ & Labor intensity in final production & 0.5 \\
$\epsilon$ & Elasticity of substitution 1/(1- $\epsilon)$ & 0.8 \\
$\delta$ & Degree of knowledge diffusion & 0.5 \\
$\tau$ & Trade cost & 1.7 \\
$f$ & Fixed operating cost & 1 \\
$\gamma$ & R\&D elasticity of labor & 0.2 \\
$\xi$ & R\&D efficiency & 0.3965 \\
$\psi$ & US labor union bargaining power & $0.6274 \rightarrow 0.5055$ \\
$\psi^{*}$ & UK labor union bargaining power & $0.6443 \rightarrow 0.6091$ \\
$\chi$ & US union wage orientation & 1.4419 \\
$\chi^{*}$ & UK union wage orientation & 2.0968 \\
$m$ & US unemployment benefits & 0.1118 \\
$m^{*}$ & UK unemployment benefits & 0.3229 \\
$\bar{L}$ & US labor force & 4.03 \\
$\bar{L}^{*}$ & UK labor force & 1 \\
\hline \hline
\end{tabular}

of intermediate goods and labor. ${ }^{5}$ We set the elasticity of substitution across intermediate varieties to $1 /(1-\epsilon)=5$, yielding a price-cost markup of $1 / \epsilon=1.25$, which is within the range of estimates presented by Britton et al. (2000) and Gali et al. (2007).

Next, adapting the methodology of Chu et al. (2016), we use (12) with the labor income share data shown in Figure 3(a) to generate time series data for union bargaining power in the US $(\psi)$ and the UK $\left(\psi^{*}\right)$. The calibrated data are plotted in Figure 3(c). The solid line shows that $\psi$ falls from 0.6274 to 0.5055 in the US, and the dashed line indicates that $\psi^{*}$ falls from 0.6443 to 0.6091 in the UK, over the period of analysis. The greater fall in union bargaining power in the US stems from the larger decline in the labor income share.

We then regress national employment rates, shown in Figure 3(b), on union bargaining power to calibrate parameter values for union wage orientation and unemployment benefits in each country. ${ }^{6}$ The resulting parameter values are $\chi=1.4419$ and $m=0.1118$ for the

\footnotetext{
${ }^{5}$ From (12), the lower and upper and bounds of labor income share are $\beta$ and $1-\alpha$.

${ }^{6}$ Specifically, we estimate the following regression function for each country: $L_{t} / \bar{L}=B_{0}+B_{1} \psi_{t}$. Referencing (13), the estimates of $B_{0}$ and $B_{1}$ yield unemployment benefits as $m=\beta /\left(B_{0} \bar{L}\right)$ and union wage orientation as $\chi=1-\left(m B_{1} \bar{L}\right) /(1-\alpha-\beta)$.
} 


\section{Figure 3: The Effects of Changes in Bargaining Power $\left(\psi, \psi^{*}\right)$}

(a) Labor Income Share
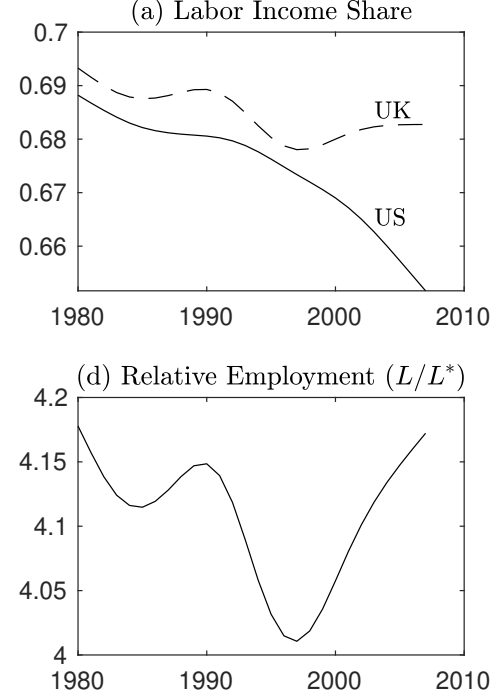

(g) Output Growth Rate $(g)$

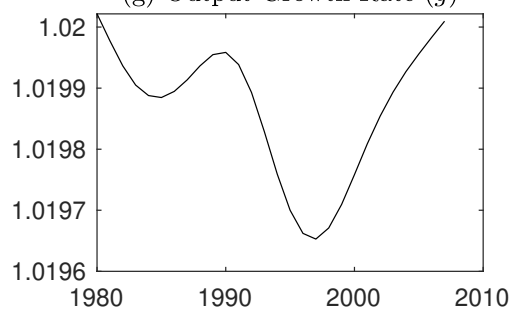

(j) UK Output $\left(Y_{0}^{*}\right)$

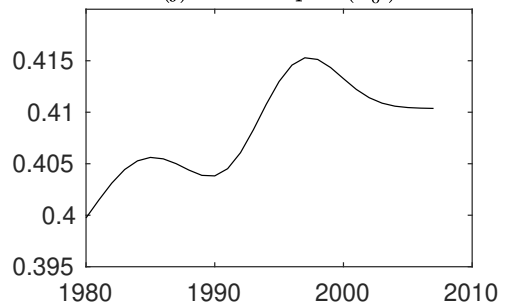

(b) Employment Rate

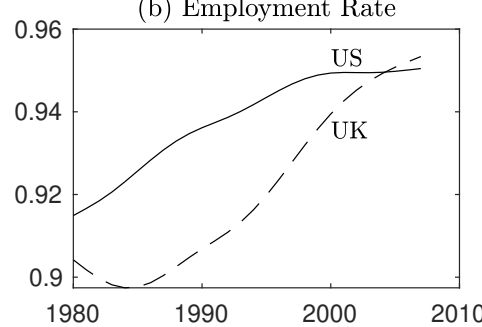

(e) Industry Share $(s)$

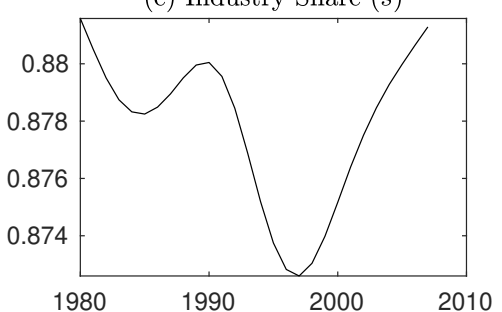

(h) Market Entry $\left(N_{0}\right)$

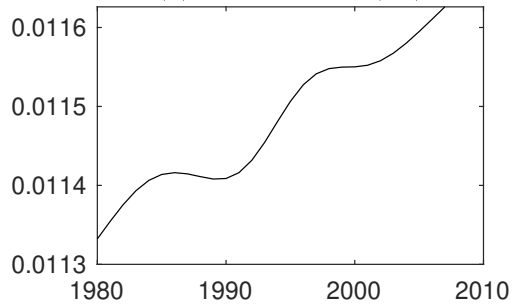

(k) US Welfare $(U)$

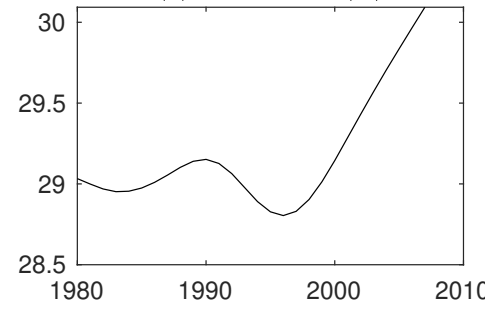

(c) Bargaining Power $\left(\psi, \psi^{*}\right)$

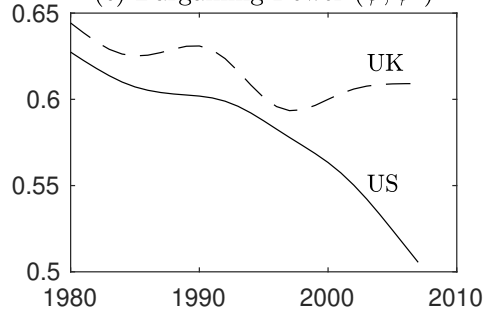

(f) Relative Productivity $(\tilde{\theta})$

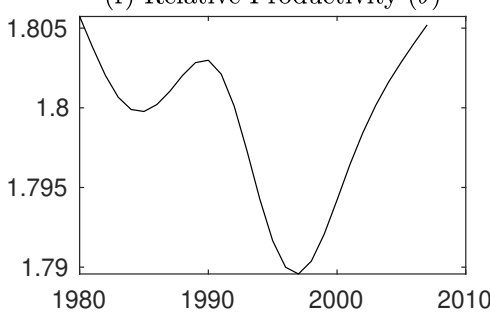

(i) US Output $\left(Y_{0}\right)$

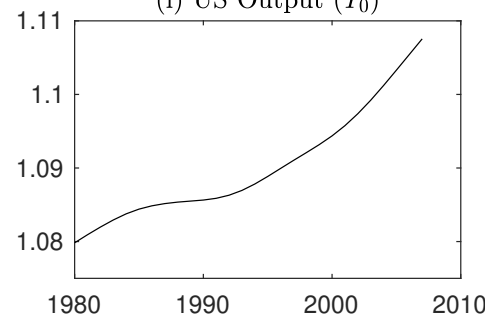

(l) UK Welfare $\left(U^{*}\right)$

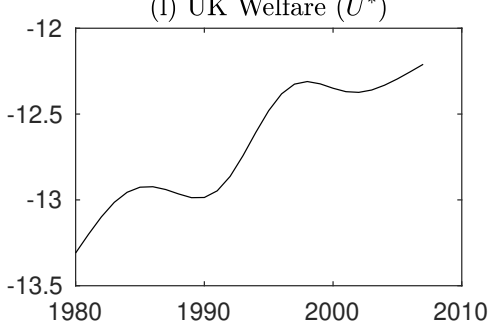

In Panels (a) through (c), the solid and dashed lines show values for the US and the UK. Panels (a) and (b) plot HP-filtered trends for labor income shares of GDP and national employment rates. The calibrated values for union bargaining power are shown in Panel (c). In Panels (d) through (l), the solid lines plot values for the indicated variable. Data source: OECD Annual Indicators on Unit Labor Costs, US Bureau of Labor Statistics, and UK Office for National Statistics. 
US, and $\chi^{*}=1.4419$ and $m^{*}=0.3229$ for the UK, suggesting that labor unions are wageoriented in both countries. Referencing (13), the calibrated parameters yield the time series data for relative employment plotted in Figure 3(d), where we have normalized the UK labor force to $\bar{L}^{*}=1$ and set the US labor force to $\bar{L}=4.03$, matching the relative labor force of the US in $1980 .^{7}$

In the intermediate sector, the degree of knowledge diffusion is fixed at $\delta=0.5$, a value that is within the range of estimates reported by Bloom et al. (2013) and that yields a certain technological proximity between the US and the UK. We adopt $\tau=1.7$ for the trade cost, based on the estimates of Anderson and van Wincoop (2004) and Novy (2013), generating a value of $\varphi=0.1197$ for the freeness of trade. With respect to process innovation, we normalize the fixed cost of market entry to $f=1$, and then calibrate the intermediate output elasticity of productivity $(\gamma=0.2)$ and the efficiency parameter for process innovation $(\xi=$ $0.3965)$ to generate a target value for output growth of $g=1.02$ in 1980 , while satisfying the second order condition for optimal investment in $\operatorname{R} \& \mathrm{D}(\eta<1)$.

The effects of changes in union bargaining power on the key variables of our framework are plotted in Figures 3(d) to 3(1). Notably, with weaker union bargaining power $\left(\psi<\psi^{*}\right)$, the US has a greater labor supply $\left(L / L^{*}>1\right)$, and thus hosts greater shares of final good production $(y>1)$ and intermediate good production $(s>1 / 2)$, with relatively more productive intermediate firms $(\tilde{\theta}>1)$ across the period of analysis. In addition, we observe that the relative labor supply expands and contracts in tandem with the union bargaining power differential between the UK and the US: $\psi^{*}-\psi$. Following from Proposition 3, as unions in both countries are wage-oriented, adjustments in $L / L^{*}$ translate directly into changes in the rate of output growth $(g)$ through the positive correlation between the relative labor supply and the international productivity differential $(\tilde{\theta})$. Therefore, a rise in $\psi^{*}-\psi$ increases output growth, while a fall in $\psi^{*}-\psi$ decreases output growth. Overall, our calibrated model indicates that changes in union bargaining power generated a 0.0012 percentage point (pp)

\footnotetext{
${ }^{7}$ Data source: OECD Labor Market Statistics.
} 
Table 2: Simulated Effects on Growth and Welfare

\begin{tabular}{lcc}
\hline \hline Variables & US & UK \\
\hline Change in Output Growth: $\left(g_{1980}-g_{2007}\right)$ & $-0.0012 \mathrm{pp}$ & $-0.0012 \mathrm{pp}$ \\
Change in Welfare: $\left(U_{2007}-U_{1980}\right) / U_{1980}$ & $3.654 \%$ & $8.257 \%$ \\
Domestic Output Channel $\left(Y_{0}\right):$ & $3.722 \%$ & $8.396 \%$ \\
Investment Income Channel $\left(N_{0} g\right):$ & $0.003 \%$ & $0.018 \%$ \\
Output Growth Channel $(g):$ & $-0.072 \%$ & $-0.157 \%$ \\
\hline \hline
\end{tabular}

decrease in output growth between 1980 and 2007, as summarized in Table 2. Lastly, as presented in Figures 3(h) to 3(j), the decline in union bargaining power, and the corresponding increase in national labor supplies, generates expansions in US output $\left(Y_{0}\right)$ and UK output $\left(Y_{0}^{*}\right)$, inducing a rise in the level of market entry $\left(N_{0}\right)$.

Turning now to national welfare, Figures 3(k) and 3(l) indicate that changes in union bargaining power lead to welfare improvements in both the US and the UK. In order to obtain a clearer understanding of the mechanisms driving these welfare improvements, we decompose welfare adjustments into three channels. In the home country, for example, taking the total derivative of steady-state utility (34) yields

$$
d U_{0}=\frac{(1+\rho)(1-\alpha)}{\rho C_{0}} d Y_{0}+\frac{(1+\rho) f}{2(1-\eta) C_{0}} d\left(N_{0} g\right)+\frac{1+\rho}{\rho^{2} g} d g
$$

The first term on the righthand side captures the effect of a change in domestic final output $\left(Y_{0}\right)$, the second term describes the effect of a change in investment income $\left(N_{0} g\right)$, and the third term describes the effect of a change in the rate of output growth $(g)$.

We quantify the annual effect of each of the channels described above and then aggregate across the period of analysis to obtain the welfare decomposition shown in Table 2. The results show that welfare improved by $3.654 \%$ in the US and $8.257 \%$ in the UK over the period of analysis. In both countries, the general decline in union bargaining power caused an expansion in domestic output that subsequently generated the largest improvement in welfare. We also observe, however, that the small decrease in rate of output growth brought about a 
significant reduction in the welfare levels of both countries.

\section{Conclusion}

This paper has examined how unionization affects economic growth through its influence on industry location patterns. We introduce a two-country model of endogenous growth and endogenous market structure. Intermediate firms invest in process innovation to lower their

production costs, and supply differentiated varieties to final good producers. International trade costs on intermediate goods ensure that the country with the larger market (i.e., greater labor supply) hosts a greater share of industry. In addition, imperfect knowledge diffusion between countries links the strength of knowledge spillovers with the geographic concentration of industry generating a positive relationship between industry concentration and the rate of economic growth.

We use the framework to study the effects of changes in labor union orientation and union bargaining power on the output growth rate. An increase in the wage orientation of the labor union in the large country reduces its labor supply, lowering the level of industry concentration and raising the rate of economic growth. The effect of an increase in union bargaining power, however, depends on the orientation of the union. When the union is wage-oriented the labor supply contracts, reducing industry concentration and slowing output growth. And, when the union is employment-oriented, the labor supply expands, increasing industry concentration and accelerating economic growth.

In order to explore the welfare implications of unionization, we calibrate our model using labor market data for the US and the UK between 1980 and 2007. Our numerical analysis suggests that the general decline in union bargaining power observed in these countries leads to welfare improvements that are for the most part driven by expansions in national output levels. We also find that a fall in the rate of output growth leads to small welfare reductions for both countries. 


\section{Appendix A}

In this appendix, we derive the equilibrium industry location pattern $\left(s_{R, t}\right)$ described by (25). First, from (21), with free market entry reducing firm value to zero $\left(V_{t}=V_{t}^{*}=0\right)$, from (21) we find that profit is the same for all firms: $\pi_{t}=\pi_{t}^{*}$. We rewrite this condition using (16) with (15), $y_{t} \equiv Y_{t} / Y_{t}^{*}, \tilde{\theta}_{t} \equiv \theta_{t} / \theta_{t}^{*}$ and $\eta \equiv \gamma \epsilon /(1-\epsilon)$ to obtain

$$
\left(1-\varphi \tilde{\theta}_{t}^{\eta}\right)=y_{t}\left(\tilde{\theta}_{t}^{\eta}-\varphi\right)\left(\frac{P_{Z, t}}{P_{Z, t}^{*}}\right)^{\frac{\epsilon}{1-\epsilon}}
$$

where, referencing (9), the price indices for intermediate varieties in home and foreign are

$$
P_{Z, t}=p_{i, t} N_{t}^{-\frac{1-\epsilon}{\epsilon}}\left(s_{t}+\varphi s_{t}^{*} \tilde{\theta}_{t}^{-\eta}\right)^{-\frac{1-\epsilon}{\epsilon}}, \quad P_{Z, t}^{*}=p_{i, t} N_{t}^{-\frac{1-\epsilon}{\epsilon}}\left(\varphi s_{t}+s_{t}^{*} \tilde{\theta}_{t}^{-\eta}\right)^{-\frac{1-\epsilon}{\epsilon}} .
$$

Substituting (A.2) with $s_{t}^{*}=1-s_{t}$ into (A.1) delivers (25). Next, we derive $y_{t} \equiv Y_{t} / Y_{t}^{*}$ in (25) as follows. Combining (5), $\alpha Y_{t}=P_{Z, t} Z_{t}$ and $\alpha Y_{t}^{*}=P_{Z, t}^{*} Z_{t}^{*}$, we obtain

$$
\frac{Y_{t}}{Y_{t}^{*}}=\left(\frac{Z_{t}}{Z_{t}^{*}}\right)^{\alpha}\left(\frac{L}{L^{*}}\right)^{\beta}, \quad \frac{Y_{t}}{Y_{t}^{*}}=\frac{Z_{t}}{Z_{t}^{*}} \frac{P_{Z, t}}{P_{Z, t}^{*}} .
$$

Then, removing $Z_{t} / Z_{t}^{*}$ from the above two equations yields the following expression:

$$
y_{t} \equiv \frac{Y_{t}}{Y_{t}^{*}}=\left(\frac{L}{L^{*}}\right)^{\frac{\beta}{1-\alpha}}\left(\frac{P_{Z, t}}{P_{Z, t}^{*}}\right)^{-\frac{\alpha}{1-\alpha}}
$$

which can be rewritten using (A.1) to obtain $y_{t}$ as shown in (25).

\section{Appendix B}

We reduce the model to a dynamic system in three variables: the international productivity differential $\left(\tilde{\theta}_{t}\right)$, the ratio of the productivity of the home intermediate production technology in final good output to the mass of intermediate firms $\left(\lambda_{t} \equiv \theta_{t}^{\alpha \epsilon \gamma /(\epsilon-\alpha)} / N_{t}\right)$, and the ratio of 
household consumption to the mass of intermediate firms $\left(\mu_{t} \equiv C_{t}^{w} / N_{t}\right)$. We then use the reduced system to derive a sufficient condition for the stability of long-run equilibrium.

A key feature of the system is that the dynamic path of $\tilde{\theta}$ is determined independently of $\lambda_{t}$ and $\mu_{t}$. Evaluating a linear expansion of (26) around the steady-state at $\tilde{\theta}_{t+1} / \tilde{\theta}_{t}=1$ yields

$$
\frac{\partial \tilde{\theta}_{t+1}}{\partial \tilde{\theta}_{t}}=\frac{\left(1-\delta \tilde{\theta}_{t}\right)\left(1-\delta \tilde{\theta}_{t}^{-1}\right)}{1-\delta^{2}}+\frac{\left(2-\delta \tilde{\theta}-\delta \tilde{\theta}_{t}^{-1}\right)^{2} \tilde{\theta}_{t}}{1-\delta^{2}} \frac{\partial s_{R, t}}{\partial \tilde{\theta}_{t}}
$$

where we have used $1-s+\delta s \tilde{\theta}=\left(1-\delta^{2}\right) /\left(2-\delta \tilde{\theta}-\tilde{\theta}^{-1}\right)$, and the slope of the $s_{R}$ curve in Figure 1 determines the effect of changes in $\tilde{\theta}_{t}$ on the home share of intermediate firms $\left(s_{t}\right)$, as $(25)$ is satisfied at all moments in time. Setting $\tilde{\theta}_{t}$ as a state variable, stability requires $\partial \tilde{\theta}_{t+1} / \partial \tilde{\theta}_{t}<1$. Thus, using (B.1), we rewrite the stability condition as

$$
\frac{\partial \tilde{\theta}_{t+1}}{\partial \tilde{\theta}_{t}}-1=-\frac{\left(2-\delta \tilde{\theta}-\delta \tilde{\theta}_{t}^{-1}\right)^{2} \tilde{\theta}_{t}}{1-\delta^{2}}\left(\frac{\partial s_{K}}{\partial \tilde{\theta}}-\frac{\partial s_{R}}{\partial \tilde{\theta}}\right)
$$

which provides the slope ranking $\partial s_{K} / d \tilde{\theta}>\partial s_{R} / d \tilde{\theta}$ that is required for stability, as illustrated in Figure 1 and outlined in Proposition 1.

Next, we derive two differential equations to describe the evolutions of $\lambda_{t}$ and $\mu_{t}$, and show that these variables jump immediately and permanently to their steady-state values. First, using (32), we obtain the ratio of final good output to the mass of intermediate firms as

$$
\frac{Y_{t}^{w}}{N_{t}}=\lambda_{t}^{1-\nu} \Omega
$$

where $\Omega \equiv(\alpha \epsilon)^{\alpha /(1-\alpha)}\left(1-\varphi^{2}\right)^{\nu}\left\{L^{\beta /(1-\alpha)} /\left[\left(1-\varphi \tilde{\theta}^{\eta}\right)(1+1 / y)\right]^{\nu}+L^{* \beta /(1-\alpha)} /\left[\left(\tilde{\theta}^{\eta}-\varphi\right)(1+\right.\right.$ $\left.y)]^{\nu}\right\}$ is constant for a given steady-state value of $\tilde{\theta}$. Linking $\pi_{t}=(1-\epsilon) p_{t} X_{t}=[(1-\epsilon) / \epsilon] I_{X, t}$ with (23) gives $N_{t} I_{X, t}=\alpha \epsilon Y_{t}^{w}$, which in turn is substituted with (B.3) into (24) to arrive at

$$
\frac{N_{t+1}}{N_{t}}=\frac{1-\eta}{f}\left[(1-\alpha \epsilon) \lambda_{t}^{1-\nu} \Omega-\mu_{t}\right]
$$


Then, referencing (31), we express the dynamics of $\lambda_{t}$ as follows:

$$
\lambda_{t+1}=\frac{g f}{(1-\eta)\left[(1-\alpha \epsilon) \lambda_{t}^{1-\nu} \Omega-\mu_{t}\right]} \lambda_{t}
$$

where the rate of output growth $(g)$ assumes a steady-state value determined by $\tilde{\theta}$.

Turning to the dynamics of $\mu_{t}$, we use (30), (B.1), (B.2), and (B.3) to obtain the following differential equation:

$$
\mu_{t+1}=\frac{\alpha(1-\epsilon) \Omega(g f)^{1-\nu} \lambda_{t}^{1-\nu}}{(1+\rho)(1-\eta)^{1-\nu}\left[(1-\alpha \epsilon) \lambda_{t}^{1-\nu}-\mu_{t}\right]^{2-\nu}} \mu_{t}
$$

Together (B.5) and (B.6) describe the dynamics of $\lambda_{t}$ and $\mu_{t}$. We evaluate a linear expansion of the system around a steady state for which $\lambda_{t+1} / \lambda_{t}=\mu_{t+1} / \mu_{t}=1$, and thus $C_{t+1}^{w} / C_{t}^{w}=N_{t+1} / N_{t}=g$. From (B.4) and (B.5), the steady-state values of $\lambda$ and $\mu$ are

$$
\lambda=\left[\frac{(1+\rho) f g}{\alpha(1-\epsilon)(1-\eta) \Omega}\right]^{\frac{1}{1-\nu}}, \quad \quad \mu=\frac{[1-\alpha+(1-\alpha \epsilon) \rho] f g}{\alpha(1-\epsilon)(1-\eta)} .
$$

Taking a linear expansion of (B.3) and (B.4) around $\lambda$ and $\mu$, we obtain the following Jacobian matrix

$$
J=\left(\begin{array}{cc}
1+\frac{(2-\nu)[1-\alpha+(1-\alpha \epsilon) \rho]}{\alpha(1-\epsilon)} & -\left[1+(1-\nu)(1-\alpha \epsilon)-\frac{\alpha(1+\epsilon \rho)}{1+\rho}\right] \frac{(1-\nu)(1+\rho) \mu}{\alpha(1-\epsilon) \lambda} \\
\frac{(1-\eta) \lambda}{f g} & 1+\frac{\epsilon(1-\nu)(1+\rho)}{(1-\epsilon)}
\end{array}\right)
$$

where the trace and the determinant associated with $J$ are

$$
\begin{aligned}
& \operatorname{tr}(J)= 2+\frac{\epsilon(1-\nu)(1+\rho)}{(1-\epsilon)}+\frac{(2-\nu)[1-\alpha+(1-\alpha \epsilon) \rho]}{\alpha(1-\epsilon)}, \\
&|J|=\left\{1+\frac{(2-\nu)[1-\alpha+(1-\alpha \epsilon) \rho]}{\alpha(1-\epsilon)}\right\}\left[1+\frac{\epsilon(1-\nu)(1+\rho)}{(1-\epsilon)}\right]+ \\
& {\left[1+(1-\nu)(1-\alpha \epsilon)-\frac{\alpha(1+\epsilon \rho)}{1+\rho}\right] \frac{(1-\nu)(1-\eta)(1+\rho) \mu}{\alpha(1-\epsilon) f g} . }
\end{aligned}
$$


As $\lambda$ and $\mu$ are jump variables, we require two eigenvalues, $\omega_{1}$ and $\omega_{2}$, with absolute values that are greater than one for saddle point stability. The values of $\omega_{1}$ and $\omega_{2}$ are determined as a solution to the characteristic equation $\psi(\omega) \equiv \omega^{2}-\operatorname{tr}(J) \omega+|J|=0$. Substituting $\operatorname{tr}(J)$, $|J|$, and $\omega=1$ into the characteristic equation, we obtain

$$
\begin{aligned}
& \psi(1)=\frac{\epsilon(1-\nu)(2-\nu)[1-\alpha+(1-\alpha \epsilon) \rho](1+\rho)}{\alpha(1-\epsilon)^{2}}+ \\
& {\left[1+(1-\nu)(1-\alpha \epsilon)-\frac{\alpha(1+\epsilon \rho)}{1+\rho}\right] \frac{(1-\eta)(1-\nu)(1+\rho) \mu}{\alpha(1-\epsilon) f g}>0 . }
\end{aligned}
$$

As $\psi(1)=\left(1-\omega_{1}\right)\left(1-\omega_{2}\right)>0$ and $\operatorname{tr}(J)=\omega_{1}+\omega_{2}>2$, we find that $\omega_{1}>1$ and $\omega_{2}>1$, and conclude that $\lambda$ and $\mu$ jump immediately and permanently to their long-run values. Thus, the slope ranking $\partial s_{K} / \partial \tilde{\theta}>\partial s_{R} / \partial \tilde{\theta}$ is a sufficient condition for saddlepath stability.

\section{Appendix C}

Substituting (4), (12) and $\Pi_{t} / Y_{t}=(1-\psi)(1-\alpha-\beta)$ into (2), and rearranging, we obtain the following intertemporal budget constraint:

$$
\sum_{t=0}^{\infty} \frac{C_{t}}{(1+r)^{t}}=(1-\alpha) \sum_{t=0}^{\infty} \frac{Y_{t}}{(1+r)^{t}}+(1+r) A_{0}
$$

Along the balanced growth path $C_{t+1} / C_{t}=g$. Thus, substituting $C_{t}=C_{0} g^{t}, Y_{t}=Y_{0} g^{t}$, and $(1+r)=(1+\rho) g$ into (C.1), we obtain

$$
C_{0}=(1-\alpha) Y_{0}+\frac{\rho}{1+\rho}(1+r) A_{0}
$$

Because initial assets are the same for home and foreign $\left(A_{0}=A_{0}^{*}\right)$ and the total asset holdings of households equals total lending to home and foreign firms, $A_{0}+A_{0}^{*}=\left(I_{R}+\right.$ f) $n_{0}+\left(I_{R}^{*}+f\right) n_{0}^{*}$, noting that $I_{R}=I_{R}^{*}=\eta f /(1-\eta)$, we obtain $A_{0}=A_{0}^{*}=f N_{0} /(2(1-\eta))$. Substituting this expression into (C.2) yields (35). 


\section{References}

[1] Anderson, J. and van Wincoop, E. (2004) “Trade costs," Journal of Economic Literature $42,691-751$.

[2] Andolfatto, D. (1996) "Business cycles and labor-market search," The American Economic Review 86(1), 112-132.

[3] Bloom, N., Schankerman, M. and Reenen, J. V. (2013) "Identifying technology spillovers and product market rivalry," Econometrica 81(4), 1347-1393.

[4] Britton, E., Larsen, J. and Small, I. (2000) "Imperfect competition and the dynamics of mark-ups," Bank of England working papers 110, Bank of England.

[5] Carmeci, G. and Mauro, L. (2003) "Imperfect labor market and convergence: Theory and evidence in some OECD countries," Journal of Policy Modeling 25, 837-856.

[6] Chang, J., Shaw, M., and Lai, C. (2007) "Managerial trade union and economic growth," European Economic Review 51(2), 365-384.

[7] Chang, J. and Hung, H. (2016) "Trade unions, unemployment, economic growth, and income inequality," Macroeconomic Dynamics 20(1), 404-428.

[8] Chu, A., Cozzi, G., and Furukawa, Y. (2016) "Unions, innovation and cross-country wage inequality," Journal of Economic Dynamics and Control 64(C), 104-118.

[9] Clark, A. and Oswald, A. (1989) "An empirical study of union preferences," Papers 352, London School of Economics - Centre for Labour Economics.

[10] Dixit, A. and Stiglitz, J. (1977) "Monopolistic competition and optimum product diversity," The American Economic Review 67(3), 297-308.

[11] Doucouliagos, H., Freeman, R., and Laroche P. (2017) The Economics of Trade Unions: A Study of a Research Field and Its Findings, New York: Routledge.

[12] Egger, H. and Etzel, D. (2014) "Union wage-setting and international trade with footloose capital," Regional Science and Urban Economics 48, 56-67.

[13] Gali, J., Gertler, M., and López-Salido, D. (2007) "Markups, gaps, and the welfare costs of business fluctuations," Review of Economics and Statistics 89, 44-59.

[14] Irmen, A. and Wigger, B.U. (2002) "Trade union objectives and economic growth," FinanzArchiv, Public Finance Analysis 59(1), 49-67.

[15] Ji, L., Chang, J-J. and Huang, C-Y. (2016) "Unionization, market structure, and economic growth," Southern Economic Journal 82(3), 935-951.

[16] Jones, L., Manuelli, R., and Rossi, P. (1993) "Optimal taxation in models of endogenous growth," Journal of Political Economy 101(3), 485-517.

[17] Lingens, J. (2003) "The impact of a unionised labour market in a Schumpeterian growth model," Labor Economics 10, 91-104.

[18] Lingens, J. (2007) “Unions, wage setting, and economic growth," Economic Modelling $24,167-188$.

[19] Merz, M. (1995) "Search in the labor market and the real business cycle," Journal of Monetary Economics 36(2), 269-300. 
[20] Munch, J. (2003) “The location of firms in unionized countries," Scandinavian Journal of Economics 105(1), 49-71.

[21] Novshek, W. and Sonnenschein, H. (1987) "General equilibrium with free entry: A synthetic approach to the theory of perfect competition," Journal of Economic Literature 115(3), 1281-1306.

[22] Novy, D. (2013). "Gravity redux: Measuring international trade costs with panel data," Economic Inquiry 51, 101-121.

[23] Nguyen-Van, P. and Terraz, I. (2021) "When union's activity matters: The impact of union centralization on economic growth in OECD countries," Applied Economics 53(21), 2433-2446.

[24] Palokangas, T. (1996) "Endogenous growth and collective bargaining," Journal of Economic Dynamics and Control 20(5), 925-944.

[25] Palokangas, T. (2005) "International labor union policy and growth with creative destruction," Review of International Economics 13(1), 90-105.

[26] Pemberton, J. (1988) "A 'managerial' model of the trade union," The Economic Journal, 98(392), 755-771.

[27] Peretto, P. (1996) "Sunk costs, market structure, and growth," International Economic Review 37(4), 895-923.

[28] Peretto, P. (2018) "Robust endogenous growth," European Economic Review 108, 49-77.

[29] Persyn, D. (2013) "Union wage demands with footloose firms and agglomeration forces," Regional Science and Urban Economics 43, 142-150.

[30] Picard, P.M. and Toulemonde, E. (2006) "Firms agglomeration and unions," European Economic Review 50, 669-694.

[31] Ramos Parreno, J.M. and Sanchez-Losada, F. (2002) "The role of unions in an endogenous growth model with human capital," Journal of Macroeconomics 24(2), 171-192.

[32] Shister, J. (1954) “Trade-unionism, collective bargaining, and economic growth," The American Economic Review 44(2), 214-227.

[33] Smulders, S. and van De Klundert, T. (1995) "Imperfect competition, concentration and growth with firm-specific R\&D," European Economic Review 39(1), 139-160.

[34] Storm, S. and Naastepad, C.W.M. (2009) "Labor market regulation and productivity growth: Evidence for twenty OECD countries (1984-2004)," Industrial Relations 48(4), 629-654.

[35] Vernon, G. and Rogers, M. (2013) "Where do unions add value? Predominant organizing principle, union strength and manufacturing productivity growth in the OECD,” British Journal of Industrial Relations 51(1), 1-27.

[36] Young, A. (1998) “Growth without scale effects," Journal of Political Economy 106(1), 41-63. 